FILOZOFIA

Roč. 75, 2020, č. 3

DOI: https://doi.org/10.31577/filozofia.2020.75.3.5

\title{
FOUCAULT O PARRHÉSII: SOKRATES VERZUS DIOGENES ${ }^{1}$
}

VLADISLAV SUVÁK, Inštitút filozofie, Filozofická fakulta Prešovskej univerzity v Prešove, Prešov, SR

\author{
SUVÁK, V.: Foucault on parrhesia: Socrates vs. Diogenes
} FILOZOFIA, 75, 2020, No 3, pp. $224-236$

The paper deals with Foucault's last lectures at the Collège de France (1981 1984). Their main theme is relationship between subject and truth. In the Hermeneutics of the subject, Foucault starts to study a concept of the care of the self which has acquired an ethical dimension in Socrates, and wants to follow its transformations into later Greek-Roman philosophy. On the basis of three texts by Plato, he shows that the Socratic-Platonic concept of self-concern is closely connected with self-knowledge. In his last lecture entitled The courage of the truth, Foucault compares it with a Cynical approach to life. Now, he can see that there is a difference between Socrates and Diogenes that gives the Cynical way of life a different character. This difference plays an important role in the history of Western subjectivity.

Keywords: Michel Foucault - Parresia - Socrates - Diogenes

V rozhovore, ktorý poskytol Michel Foucault 20. januára 1984, takto odpovedá na otázku, či je úlohou filosofie varovat' pred nebezpečenstvom moci: Áno, pretože filosofia sa spája s tradíciou kritického myslenia, ktorá vychádza zo sokratovského imperatívu „Zaoberaj sa sám sebou!“, čo znamená „Ovládaním seba samého urob zo slobody svoju oporu!“ (Foucault 2000, 153 - 154). ${ }^{2}$ Foucault tu prisudzuje Sokratovi významné miesto $\mathrm{v}$ dejinách západného myslenia, aj ked' poznamenáva, že to platí iba do istej miery (jusqu'à un certain point). Zároveň môžeme vidiet', že starost' o seba

\footnotetext{
${ }^{1}$ Chcem sa pod'akovat' Simone Raševovej za cenné poznámky k rukopisu tohto článku.

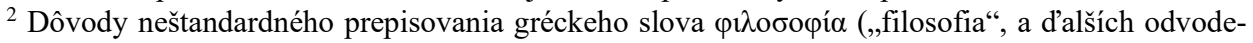
ných slov, „filosof“, „filosofický“ atd'.) s grafémou „s“ vysvetl'uje stat' uverejnená v časopise Filozofia (Suvák 2000). Používanie slova „filosofia“ v nesúlade so slovenskou jazykovou normou má okrem iného zdôraznit’ antické chápanie filosofie, ktoré sa nespája ani s vedou o najvšeobecnejších zákonoch bytia, myslenia a procesu poznania, ani s názormi na život a na svet, ani so spoločenskovedným odborom štúdia na univerzitách, ale s existenciálnou vol'bou a spôsobom života (Hadot 1981).
} 
je úzko spätá s praxou slobody a pravdou: ${ }^{3}$ „Starost' o seba samého je, pochopitel’ne, sebapoznaním - to je sokratovsko-platónska stránka - no je to aj poznanie istých pravidiel správania alebo princípov, ktoré sú pravdami, a zároveň predpismi. Starat’ sa o seba samého, to znamenalo osvojit' si tieto pravdy: na tomto mieste je etika spätá s pravdou" (Foucault 2000, $136-137$ ). ${ }^{4}$

Foucaultove prednášky na Collège de France v rokoch 1981 - 1984 zjednocuje záujem o štúdium vzt'ahu medzi subjektom a pravdou. Z hl'adiska tohto vzt'ahu predstavuje Sokrates dôležitý bod $\mathrm{v}$ dejinách západnej subjektivity a zároveň $\mathrm{s}$ tým sa mení aj prevládajúci pohl'ad na antickú filosofiu: jej centrálnym princípom nie je príkaz „Poznaj sám seba!““ (gnóthi seauton), ale „Zaoberaj sa sebou!“, „Staraj sa o seba!““ (epimelú seautú). V Hermeneutike subjektu (1981/1982) Foucault zdôvodňuje, že pre antickú filosofiu nie je prvoradá požiadavka poznat' sám seba, ale zásada starosti o seba, zahŕňajúca proces sebapoznania. Starost' o seba (epimeleia heautú) predstavuje $\mathrm{v}$ tomto kontexte súbor praktík, ktoré subjekt uplatňuje na sebe so zámerom pripomínat' si sám seba, venovat' sa sám sebe (Foucault 2001, 6).

Položme si otázku, prečo patrí Sokratovi také dôležité miesto v dejinách západnej subjektivity? Podl'a Foucaulta to vyplýva z toho, že k starosti o seba nepristupuje ako k teoretickému problému, ale uplatňuje ju prostredníctvom konkrétnych praktík. Na Sokrata sa môžeme dívat' ako na majstra starosti o seba, ktorej prisudzuje výrazne etický význam. Aspoň tak to vyplýva z trojice Platónových textov, ktoré Foucault analyzuje: Obrana Sokrata, Alkibiadés I. a Lachés. Všetky tri tematizujú starost' o seba, aj ked' každý z nich rozvíja iné chápanie starosti. Stručne naznačíme, k čomu dospieva Foucaultovo čítanie týchto textov. Na ich základe sa pokúsime vymedzit' sokratovsko-platónske chápanie starosti o seba, aby sme ho mohli porovnat's kynickým prístupom k životu, ktorému sa venuje Foucaultov posledný kurz na Collège de France Odvaha k pravde (1983/1984). V Hermeneutike subjektu sú kynici začlenení do sokratovskej tradície starosti o seba; v Odvahe k pravde sa však ukazuje, že medzi Sokratom a Diogenom je určitý rozdiel, ktorý dáva kynickému spôsobu života iný

\footnotetext{
${ }^{3}$ Foucault používa pre grécky výraz epimeleia francúzsky ekvivalent le souci, ktorý nemá význam „systematickej starostlivosti o niečo alebo niekoho“, ale skôr „starosti“ ako obavy, ktorá nás núti k zmene životného postoja a upriameniu pozornosti na to, čo je pre nás dôležité. Porov. taktiež lat. výraz cura (,starost’ o niečo alebo niekoho“, „obavy“, fyzické alebo duševné „,'ažkosti“, „úsilie o niečo“), ktorý v sebe spája obavy o vlastný život so snahou o ich prekonanie (Foucault 2009, $109-110)$.

${ }^{4}$ Na podporu Foucaultovej hypotézy by sme mohli uviest' príklad Aristippa ako jedného z najznámejších Sokratových nasledovníkov: súčasní historici ho označujú za otca hedonizmu (etickým ciel’om je telesná rozkoš zakúšaná v prítomnej chvíli), ale najstaršie správy ho zobrazujú ako typického sokratovca, teda slobodomysel'ného človeka, ktorý sa zaoberal výlučne praktickou etikou starosti a jeho maximou bolo „žit' kdekol'vek ako cudzinec“ (Xenoph., Mem. 2.1.11 - 13).
} 
charakter. Našou úlohou bude pozriet' sa bližšie na tento rozdiel - čo znamená z hl'adiska vzt'ahu medzi subjektom a pravdou?

\section{Sokrates v Obrane}

Platónova Obrana nezobrazuje Sokrata ako filosofa, ktorý disponuje nejakým vyšším poznaním, ale ako človeka, ktorý všetkých nabáda k starosti o seba (Foucault, 2001, 7 - 10). V pasáži 29d - 30a Sokrates hovorí svojim žalobcom a sudcom, že aj keby mu niekto ponúkol možnost' nezomriet' pod podmienkou, že zmení spôsob svojho života, musel by mu povedat', že to neurobí - d'alej sa bude pýtat' svojich spoluobčanov, či sa nehanbia za to, že sa starajú o peniaze, aby ich bolo čo najviac, o čest' a slávu, ale nestarajú sa o rozum, pravdu a dušu, aby bola čo najlepšia. Filosofovat' tu znamená starat' sa o rozum, pravdu a dušu, čiže nezanedbávat' to, čo je v živote dôležité. Presnejšie, je to vytváranie vzt’ahu k sebe a druhým, lebo Sokrates jedným dychom dodáva, že boh ho povolal, aby všetkých, mladých či starých, cudzincov či domácich nútil svojimi rozhovormi $\mathrm{k}$ tomu, aby neprestávali so starost'ou o seba, a to aj vtedy, ked' si myslia, že to nepotrebujú, lebo sa už o seba postarali.

V d’alšej pasáži (Apol. 30c - 31c) Sokrates ukazuje Aténčanom, kto z nich utrpí väčšiu škodu: ked' ho nebudú počúvat', uškodia viac sebe ako jemu - keby to nebol Sokrates, boh by k nim poslal niekoho iného, aby ich napomínal, že sa majú starat' väčšmi o seba ako o peniaze, lebo zdatnost' konania (areté) nevzniká z peňazí, ale zo zdatnosti vznikajú peniaze aj všetky ostatné veci, ktoré považujú l’udia za dobré. ${ }^{5}$ Boh posiela Sokrata k Aténčanom s dôležitou úlohou - je natol'ko dôležitá, že pre ňu zanedbáva svoje súkromné veci a znáša následky tohto zanedbávania, no aj napriek tomu neprestajne pracuje pre druhých a usiluje sa každému človeku dopomôct' $\mathrm{k}$ tomu, aby sa staral o vlastné zdokonalenie. Sokrates považuje starost' o seba a druhých za misiu a sám seba za božieho vyslanca. Ako môžeme vidiet', epimeleia heautú nie je stav vedenia a nedá sa redukovat' ani na dosiahnuté poznanie o sebe, ale je to trvalá činnost' - skúmanie, ktoré sa spája s hladaním dobre vedeného života. Podl'a Sokrata ide o život, ktorý je hodný toho, aby ho človek žil (Apol. 38a).

Posledná pasáž (Apol.36b - 36c) sa týka trestu, ktorý má Sokrates podl’a dobovej súdnej procedúry navrhnút' sám pre seba. Aký trest si zaslúži za to, že sa nestaral o zarábanie peňazí, o hospodárstvo, o vojenské hodnosti, o úrady, lebo tým by neprospel sebe ani druhým? Namiesto toho nabádal každého jedného človeka, aby sa o tieto veci nezaujímal, pokial' sa nedokáže postarat' sám o seba.

Čo vyplýva z Foucaultovho čítania Platónovej Obrany? Sokrates je vykreslený ako človek, ktorý nabáda druhých k odvahe starat' sa o seba. K tejto činnosti ho núti

\footnotetext{
${ }^{5}$ Sokrates tu stavia proti sebe konvenčné chápanie starosti s etickou starost’ou o seba.
} 
boh, ktorý sa stará o Aténčanov (Apol. 28d) - keby k nim neposlal Sokrata, vyslal by niekoho iného. Tretia pasáž je zaujímavá tým, že stavia Sokrata do pozície človeka, ktorý je nútený do istej miery zanedbávat' starost' o seba kvôli starosti o druhých. ${ }^{6}$ Ďalší dôležitý moment sa týka povahy starosti, ktorá má formu prebudenia. Človek musí otvorit' oči, ak chce pochopit', že sa treba starat' o seba, inak prespí celý svoj život (Apol. 31a). Posledný bod sa viaže k úlohe Sokrata. On sám sa pripodobňuje k ovadovi, ktorý sedí na obci ako na nejakom vel'kom nemotornom koni a pobáda ho k činnosti (Apol. 30e). Foucault vyvodzuje zo svojho čítania Obrany, že „Sokrates je a vždy bude človek spätý so starost'ou o seba. V sérii d'alších textov (stoikov, kynikov, no najmä u Epiktéta) uvidíme, že Sokrates je vždy bytostne a zásadne človekom, ktorý zastavuje mladých l'udí na ulici a hovorí im: Musíte sa o seba starat!'“ (Foucault, 2001, 10)

Analýza Obrany tvorí úvodnú prednášku Hermeneutiky subjektu a naznačuje hlavnú tému celého kurzu - vyplýva z nej, že Sokrata by sme mohli postavit' na začiatok tradície etickej starosti o seba, ktorú budú rozvíjat' d’alšie generácie filosofov, najmä stoikov a kynikov. Sokrates nie je iba majster starosti o seba, ale aj človek, ktorý hovorí za každých okolností pravdu, lebo bez nej by epimeleia nebola možná. Čo môžeme vyčítat' z Obrany, ked' sa na ňu pozrieme z hl'adiska vzt'ahu medzi subjektom a pravdou? Sokratovský rozhovor konfrontuje subjekt s poznaním, že to, čo si myslel, že vie, vlastne nevie. Subjekt si priznáva pravdu o sebe a druhých, čím si vytvára vzt’ah sám $\mathrm{k}$ sebe - chápe, že konvenčné chápanie starosti nevedie k dobrému životu. Ten závisí od rozpoznania, ktoré veci sú v živote dôležité. Sebapoznanie hrá v procese sebautvárania dôležitú úlohu, ale jeho ciel'om je trvalá starost' o seba. Rozdiel medzi Sokratom ako Majstrom starosti a účastníkmi, ktorých nabáda k starosti, tkvie v tom, že pre Sokrata je starost' o druhých zároveň formou starosti o seba. Hra pravdy a nepravdy, ktorú rozohráva s druhými, je hrou pravdy a nepravdy, ktorú musí vztiahnut' sám k sebe. ${ }^{7}$

V Obrane sa tematizuje starost' o seba ako činnost', ktorú uplatňuje jednotlivec počas celej svojej existencie. Naproti tomu v Aklibiadovi I. sa epimeleia heautú týka najmä jednej etapy l'udského života - prechodu do dospelosti. Foucault si myslí, že toto druhé chápanie starosti je pre sokratovsko-platónske myslenie dôležitejšie a že téma starosti ako celoživotnej praxe sa rozvinie až v epikureizme a stoicizme, teda v ére „kultúry seba samého“ (Foucault 2001, 38).

\footnotetext{
${ }^{6}$ Táto Foucaultova poznámka nie je celkom jasná, ale naráža zrejme na úlohu Majstra, v ktorej musí učitel' súčasne nabádat žiakov k starosti o seba aj uplatňovat' túto starost' sám na seba, čo nie je vždy jednoduché.

${ }^{7}$ Foucault hovorí, že bytostnou, fundamentálnou a pôvodnou funkciou Sokrata v Obrane (ako fundamentálnom Platónovom texte) je dodávat' druhým odvahu k starosti o seba (Foucault 2001, 7).
} 


\section{Sokrates v Alkibiadovi I}

Text, ktorý jedna čast' moderných komentátorov pokladá za nepravý Platónov dialóg a druhá čast' za jeden z prvých Platónových dialógov, sa sústred'uje okolo témy starosti o seba. Alkibiadés I. predkladá „teóriu starosti“, takže ovel’a viac ako praktiky vzt'ahovania $\mathrm{k}$ sebe problematizuje podstatu starosti o seba, aj ked' používa množstvo príkladov z oblasti techné. Foucault vztiahne neskôr k Alkibiadovi I. „vel'ký paradox platonizmu.“

O čo ide v tomto nenápadnom, ale dôležitom dialógu? Sokrates sa rozpráva s Alkibiadom - ctižiadostivým mladíkom, nástupníkom vynikajúceho rodu, ktorý má velké politické ambície - a ukazuje mu, že je privel'mi domýšlavý, ked' sa chce ujat' vlády v obci, radit' jej a súperit' so spartskými a perzskými vládcami, ale nenaučil sa, čo treba vediet', aby mohol človek vládnut' - nenaučil sa starat' o seba. Mal by sa to naučit' čo najskôr, lebo v pät'desiatich rokoch bude už neskoro (Alcib. I. 127d-e).

Foucault poukazuje na niekol'ko dôležitých aspektov starosti v Alkibiadovi I., ktoré sa navzájom prelínajú a doṕňajú. Predovšetkým je to politický aspekt: starost' o druhých, s ktorou sa spája vládnutie, predpokladá schopnost' starat' sa sám o seba. Ďalší aspekt súvisí s výchovou: Alkibiada nemôže naučit' starat' sa o seba niekto, kto je sám nevzdelaný, alebo sa zaujíma iba o jeho krásne telo. Ďalší aspekt sa týka veku: starat' sa o seba musí vediet' ten, koho už nevedie poručník, takže vo všetkých situáciách sa musí spol'ahnút' sám na seba. V Alkibiadovom prípade ide o začiatok jeho politickej kariéry. Posledný aspekt vyplýva z toho, že Alkibiadés si neuvedomuje, o čo sa má starat': vie, že sa chce postarat' o celú obec, ale nevie, ako sa má o ňu starat' - nevie, čo je predmetom dobrej vlády v obci (Foucault 2001, 37 - 39).

Centrálna otázka dialógu sa týka vymedzenia onoho ,ja sám“, „sám seba“ (auto to auto; Alcib. I. 129b) v požiadavke „Staraj sa o seba!“? Sokrates nehovorí Alkibiadovi, že sa musí starat' o seba, lebo už dospel a mal by vediet', čo znamená byt' mužom. Sokrates kladie ovel'a zložitejšiu otázku. Moderným jazykom by sme mohli povedat', že sa pýta na to, čo obracia jednotlivca $\mathrm{k}$ sebe samému - pýta sa na subjekt. Zároveň sa pýta na to, o čo sa musí starat' človek, ktorý sa chce starat' o druhých. Príkaz „Staraj sa o seba!“ znamená, že si to ty, kto sa musí o seba starat'. Inými slovami to, o čo sa jednotlivec musí starat', je totožné s tým, kto sa stará. Predmet starosti je rovnaký ako subjekt starosti. Preto potrebujeme bezpodmienečne vediet', čo je toto ,ja sám“.

Ako by som mohol definovat' svoje ,ja“? Platónova odpoved’ je zrejmá: „Ja“ je duša. Ak nám niekto prikazuje poznat sám seba (ako delfský Apollón), káže nám poznat' svoju dušu (Alcib. I. 130e). Človek sa musí starat' o svoju dušu, lebo ona jediná je totožná s, ja“ (Alcib. I. 130d, 132c); ostatné veci (telo, majetok, pocty atd’.) sú iba tým, 
čo duša používa - podobne ako remeselník používa svoje nástroje (Alcib. I. $129 \mathrm{c}-\mathrm{d}){ }^{8}$ Sokrates vysvetl'uje Alkibiadovi, čo robíme, ked' chceme nejakú vec uchopit': na to, aby sme ju uchopili, používame ruky; kto používa ruky? - subjekt. Rovnakým spôsobom použiva subjekt oči, ked' sa chce na niekoho pozriet' a tak d'alej. To však neznamená, že vzt’ah medzi dušou a telom by sme mali chápat' inštrumentálne - skôr ide o jedinečnú transcendentnú pozíciu subjektu vo vzt'ahu ku všetkému, čo ho obklopuje, vrátane druhých l'udí. ${ }^{9}$ Foucault z toho vyvodzuje, že Platón v Alkibiadovi I. nechápe dušu ako substanciu, ale ako subjekt (Foucault 2001, 56).

Alkibiada I. by sme mohli postavit' na pomyselný začiatok filosofickej starosti o seba, ktorá sa rozvinie do kultúry samého seba (1. - 2. stor. po Kristovi). Zároveň vidíme, že Alkibiadés I. je platónskym riešením problému, lebo starost' o seba uskutočňuje cez sebapoznanie, ktoré chápe ako najvyššiu formu starosti. Pre platonizmus a novoplatonizmus je charakteristické presvedčenie, že prístup k pravde umožňuje sebapoznanie - iba tak môže človek uvidiet' to, čo je v duši, teda v subjekte božské. Poznat' sám seba, poznat' božské, uvidiet' božské v duši je zmyslom platónskej a novoplatónskej starosti o seba. Foucault spája takéto chápanie starosti s ,vel'kým paradoxom platonizmu“, ktorý bude hrat' dôležitú úlohu v dejinách západnej filosofie až do 17. storočia. Pre platonizmus platí, že prístup k pravde sa môže uskutočnit’ iba s ohl'adom na božské, ktoré je späté s dušou, a iba s ohl'adom na dušu, ktorá je spätá s božským. Úzky vzt'ah medzi dušou a božským - medzi dušou ako božskou a božským ako dušou - je v platonizme podmienkou prístupu k pravde. $Z$ tohto prostredia vyrastú rôzne duchovné hnutia, ktoré vyvrcholia v gnosticizme. Zároveň vidíme, že platonizmus je živnou pôdou pre rozvoj toho, čo by sme mohli nazvat' „racionalitou“ a čo sa zaobíde bez duchovnosti, bez spirituality. Platonizmus tak zohráva dvojakú úlohu v európskom myslení: na jednej strane kladie dôraz na nevyhnutnú podmienku spirituality pre prístup $\mathrm{k}$ pravde, a zároveň vstrebáva spiritualitu do samotného poznania, do poznania seba, do poznania božského, do poznania esenciálneho (Foucault, 2001, 75 - 76).

\section{Sokrates v Lachétovi}

Rozprava v Platónovom Lachétovi vyústuje do celkom iného chápania starosti: to, o čo sa musí človek starat', nie je duša, ale život (Foucault 2009, 109 - 144). Zároveň sa tu dostáva do popredia téma parrhésie (úprimné hovorenie pravdy), ktorá bola dôležitá aj v Akibiadovi I. (Sokrates hovoril s Alkibiadom úprimne, bez postranných

\footnotetext{
${ }^{8}$ Požiadavka starosti o dušu sa objavuje v rôznych kontextoch vo viacerých Platónových textoch. Porovnaj Apol. 29a; Crat. 440c; Phd. 108c; Resp. 368d, 369a atd'.

${ }^{9}$ Foucault upozorňuje, že grécke sloveso chrésthai, ktoré prekladáme slovom ,„používat", má široké spektrum významov, napr. spojenie theóis chrésthai neznamená „využívat' bohov“ za nejakým účelom, ale „mat’ náležitý vzt'ah k bohom“, „ctit” si bohov“ (Foucault, 2001, 55 - 56).
} 
úmyslov), ale zatienila ju téma duše. Parrhésia vstupuje v Lachétovi do hry preto, lebo $\mathrm{v}$ ňom nejde o teoretické uchopenie starosti, ale o praktické kroky, ktoré vedú $\mathrm{k}$ jej uskutočneniu. Lachés je konkrétnym príkladom etickej parrhésie, praxe veridikcie, teda toho, čo označovala Platónova Obrana ako Sokratove praktiky (Foucault 2009, 145). ${ }^{10}$

Parrhésia sa objavuje v Lachétovi od samého začiatku: úspešný priebeh rozpravy predpokladá úprimnost' a otvorenost' zo strany všetkých zúčastnených. ${ }^{11}$ Rozprava spočiatku pripomína politickú debatu, v ktorej treba rozhodnút' o spore hlasovaním, ale Sokrates - odvolávajúc sa na závažnost’ témy, ktorou je výchova synov núti ostatných, aby rozhodli o tejto veci na základe znalosti (epistémé; Lach. 184e8).

Celkový obrat v rozprave umožňuje hra parrhésie a éthosu (Foucault 2009, 131 - 144). Ako k nej dochádza? Sokrates presadzuje dialektickú rozpravu založenú na krátkych otázkach a odpovediach, všetci to však nechápu - Nikias im preto vysvetl'uje, že Sokrates sa rozpráva iba s tými, ktorým záleží na rozhovore, a nakoniec ich vždy dovedie k tomu, aby prešli od predmetu rozpravy k rozhovoru o sebe samých (Lach. 187e-188a). Prijatie parrhésiastickej hry si vyžaduje odvahu od tých, ktorí vstupujú do rozhovoru. Ciel’om hry je priviest' každého účastníka rozpravy $\mathrm{k}$ tomu, aby „podal výklad sám o sebe“ (didonai peri autú logon; Lach. 187e10). Foucault interpretuje toto spojenie ako nutnost' ukázat' vzt’ah medzi logom a samým sebou: dokážeš podat' logos sám o sebe? Sokrates sa týmto nepýta na nejakú schopnost' človeka, ale smeruje k jeho životu: akým spôsobom života žije? (Lach. 187e10 - 188a2). Parrhésiastický diskurz sa sústred'uje na oblast' existencie, na tropos života (Foucault 2009, 134). Sokrates sa nezaujíma o určenie života ani o hl'adanie modu bytia, ktorý by sa zakladal na ontológii duše (ako v Alkibiadovi I.) - zaujíma sa o životný štýl (bios), o konkrétnu podobu, ktorú každý z nás dáva svojmu životu.

Parrhésia („odvaha hovorit' pravdu“) sa zakladá na štýle života. Lachés súhlasí s rozpravou preto, lebo vidí súlad medzi Sokratovým životom a praxou slobodnej rozpravy. Pre Foucaulta je toto miesto zásadné, pretože vytvára spojitost' medzi starost'ou o seba a sokratovským diskurzom: parrhésia sa riadi princípom „Staraj sa o seba!“ Jej bytostným záujmom je život, ktorý si volíme. Zmyslom parrhésiastických praktík je starost' o seba, pričom pravým vychovávatel'om starosti nie je ani Sokrates ani nejaký odborník v tradičnom zmysle, ale sama reč, logos.

Antický podtitul Lachéta znie: O odvahe. V tomto duchu číta Platónov dialóg väčšina antických aj moderných komentátorov - Čo je podstatou odvahy? Foucaultovo čítanie umožňuje pozriet' sa na odvahu z iného uhla: pravda o odvahe a odvaha

\footnotetext{
${ }^{10}$ Veridikciu Foucault chápe ako hovorenie pravdy, ktoré je vždy zároveň praxou (Foucault 2009, $285-286$ )

${ }^{11}$ Plat., Lach. 179a5, 179a8, 179b5, 179d4, 179e6.
} 
hovorit' pravdu sú v Lachétovi bytostne späté. Otvorené hovorenie sa tu spája s nutnost'ou uplatnit' parrhésiu na sebe samom, čo je zmyslom starosti o seba.

\section{Alkibiadés I. verzus Lachés}

Medzi Lachétom a Alkibiadom I. je podl'a Foucaulta zásadný rozdiel, ktorý si môžeme priblížit' za pomoci dvoch aspektov. Prvý má sociálny charakter, lebo v Lachétovi Sokrates diskutuje o potrebe starosti so zrelými a váženými Aténčanmi, ktorí už mnohokrát prejavili odvahu, aj ked' nevedia podat jej výklad. Dôvod, prečo sú ochotní viest' dialóg so Sokratom, vychádza z toho, že nikto nepochybuje o Sokratovej zdatnosti, ktorú prejavoval počas celého života. V Alkibiadovi I. je situácia celkom iná, lebo Sokrates sa tu zhovára s neskúseným ctižiadostivým mladíkom, ktorý si myslí, že je povolaný postavit' sa na čelo Atén. Druhý aspekt súvisí s dramatickou výstavbou dialógu: Lachés sa končí konštatovaním, že odvahu zatial' nikto dostatočne nevymedzil, preto ju musia d'alej hl'adat' (a uskutočňovat'), zatial' čo Alkibiadés I. dospieva k poznaniu duša ako toho, na čo sa musí zamerat' naša pozornost'.

Aj napriek neprehliadnutel'ným rozdielom majú Alkibiadés I. a Lachés spoločné niečo, čo je dôležité nielen z hl'adiska sokratovskej tradície myslenia, ale aj z hl'adiska celej západnej filosofie: $\mathrm{v}$ obidvoch dialógoch (a mohli by sme pridat takisto Platónovu Obranu) slúži Sokratova parrhésia na to, aby priviedla účastníkov rozhovoru k potrebe podat výklad o nich samých (didonai logon). Vd’aka parrhésii každý dospieva k poznaniu, že sa musí o seba starat'. Sokrates sa prejavuje v konečnom dôsledku ako učitel' starosti. Tým, že sa stará o druhých, nabáda ich k ustavičnej starosti o seba.

Foucault ukazuje, že Alkibiada I. a Lachéta by sme mohli spojit' (vel'mi schematicky) s dvoma rozdielnymi pohybmi v západnej filosofii. Sokratovská parrhésia vedie tých, ktorí majú podat' výklad sami o sebe, bud' k potrebe poznat' svoju dušu ako niečo odlišné od tela (Alkibiadés I.), alebo k požiadavke dat' svojej existencii určitý štýl (Lachés). Prvá línia sa spája s metafyzikou duše, druhá so spôsobom života. Parrhésia tak môže produkovat protichodné pohyby, ktoré vytvárajú odlišné histórie. Na jednej strane je to história metafyziky duše, na druhej strane história štýlu života. Práve tejto druhej histórii (skrytej a marginalizovanej v dejinách západného myslenia) sa chce Foucault venovat' vo svojom poslednom kurze na Collège de France. Predmetom tejto histórie by mal byt' život ako možné dielo umenia.

Z hl'adiska estetiky existencie je ,sokratovský moment“ zaujímavým miestom, lebo spája tradičnú požiadavku starosti o seba s pravdivým diskurzom, pravdivým životom, životom v pravde. Foucault zároveň poznamenáva, že Sokrata by sme nemali pokladat' za vynálezcu estetiky existencie - skôr by sme mohli hovorit' o tom, že jej dal výrazný etický rozmer. Téma pravdivého života, hladania krásnej existencie $\mathrm{v}$ praxi pravdivého hovorenia, sa naplno rozvinie $\mathrm{v}$ kynizme. $\mathrm{V}$ deviatej prednáške 
Odvahy k pravde Foucault hovorí svojim poslucháčom, že sa bude zaoberat' príkladom kynikov, ale vôbec netuší, kol'ko času mu to zaberie (Foucault 2009, 152). Nakoniec sa zdrží pri kynikoch až do konca kurzu, lebo v nich objaví d’alší kl’účový moment $\mathrm{z}$ hl'adiska dejín subjektivity. ${ }^{12}$

\section{Kynický spôsob života}

Pre históriu estetiky existencie, ktorá stavia do centra záujmu život ako dielo umenia, je dôležitá skúška. ${ }^{13}$ Vzt'ah k sebe si môžeme predstavit' ako hru pravdy a nepravdy: subjekt musí získat' určitý súbor poznatkov (mathémata), ale potrebuje vediet' aj to, ako ich má uplatnit'. Druhá stránka je výsledkom vytrvalého cvičenia (askésis), ktoré uskutočňuje subjekt sám na sebe. Okrem poznatkov je potrebná aj skúška samého seba, ktorá sa môže uskutočnit' až vtedy, ked' má subjekt odvahu hovorit' pravdu. Tu vstupuje do hry parrhésia, ktorá nadobúda v sokratovskej tradícii význam etickej starosti o seba. Parrhésiastická hra sa prejavuje v dvoch rovinách: 1.) v odvahe povedat' pravdu niekomu, komu chcem pomôct' a priviest' ho k etickému utváraniu samého seba; 2.) v odvahe vyjavit' pravdu o sebe a ukázat' sám seba takého, aký som. Týmto spôsobom uplatňujú parrhésiu kynici. Ich kritika konvenčných pravidiel života sa netýka iba vládcov a tyranov, ale aj ich samých. Parrhésia v kynizme splýva so spôsobom života.

Foucault označuje kynický postoj k pravde za nový typ parrhésie. Ak mu chceme porozumiet', mali by sme ho odliśsit' od politickej parrhésie, od odvahy povedat' pravdu vládcovi alebo Zhromaždeniu aj za cenu, že riskujeme svoje životy. ${ }^{14}$ Ale takisto by sme ho mali odlišit' od sokratovskej irónie, ktorá odkrýva nevedenie u tých, ktorí si namýšlajú, že niečo vedia. Sokrates používa iróniu v pedagogickom úsilí priviest' účastníkov rozhovoru $\mathrm{k}$ starosti o seba, pričom na seba berie riziko, že si ich znepriatelí. Pre kynického parrhésiasistu je príznačné niečo iné ako pre kritika politiky alebo ironika: kynik neriskuje život pre to, čo hovorí, ale najmä pre to, ako žije. Mohli by sme dokonca povedat', že kynikovi ovel’a menej záleží na tom, čo hovorí, než na tom, ako žije (Foucault 2009, 310). Kynik „odhal'uje“ svoj život vo všetkých významoch tohto slova. Riskuje život, lebo ho vystavuje na oči všetkým. Odhal'uje ho, ale nie tak, že by o ňom hovoril. Odhal'uje ho tým, že ho žije. Kynický život stierajúci hranice medzi verejným a súkromným sa stáva verejným škandálom (Foucault 2009, 214).

12 O kynikoch vyšlo vo Filozofii niekol'ko vynikajúcich štúdií: Flachbartová (2014), Cepko (2016), Zelinová (2016), Škvrnda (2017).

${ }^{13}$ Porovnaj rukopisnú podobu záveru kurzu Odvaha k pravde (Foucault 2009, 309 - 311).

${ }^{14}$ Foucault odkazuje najmä na Euripidove tragédie (Ión, Orestés), v ktorých sa objavuje výraz parrhésia, a ukazuje, že ide o jeden z klúčových znakov demokratickej vlády: na agore môže slobodný občan ,povedat' všetko“ (odvodené od pas = „všetko“ a rhésis = ,povedat"). Ciel'om politickej parrhésie je dobrá vláda. 
Na kynickú parrhésiu sa môžeme dívat' ako na etické zavŕšenie politickej parrhésie, lebo možnost' politickej kritiky, možnost' politického odporu vychádza z etického sebautvárania subjektu. Práve tento aspekt parrhésie Foucault pokladá za dôležitý aj pre súčasné premýšl'anie o etike a politike: žiadny odpor voči politike nie je možný bez vzt'ahu subjektu k samému sebe. ${ }^{15}$ Ak uplatníme na kynizmus tradičné kritéria filosofického spôsobu života (bios filosofikos), pochopíme, v čom sa odlišuje od iných škôl. Takmer všetky pristupujú k hovoreniu pravdy z hl'adiska otázky, aké podmienky musí spíňat' nejaká výpoved', ak má byt' uznaná za pravdivú. Kynizmus vychádza $\mathrm{z}$ inej otázky: Aká forma života vedie $\mathrm{k}$ parrhésii, teda $\mathrm{k}$ tomu, aby sme boli úprimní voči sebe aj voči druhým? Táto otázka je pre kynikov natol'ko dôležitá, že by sme prostredníctvom nej mohli charakterizovat' kynický spôsob života (bios kynikos).

Kynici pokladajú filosofiu za prípravu na život. Diogenes, prvý a najväčší kynik, hovorí, že „pre život si treba pripravit' rozum alebo povraz.“16 Foucault vidí v jeho slovách existenciálnu vol'bu: „Bud' začni žit' podl’a pravidiel $\log u$, alebo sa obes!“ (Foucault 2009, 219). Príprava na život znamená, že človek sa musí ustavične starat' o svoj život a nevzrušovat' sa malichernými záležitost'ami. ${ }^{17}$ Starost' o seba si vyžaduje, aby človek dodržiaval princípy, ktoré si určil pre život. ${ }^{18}$ Najznámejší kynický princíp vyjadruje spojenie paracharattein to nomisma (,falšovat' peniaze“, ,falšovat' mravy“), ktoré odkaze na Diogenov exil zo Sinópy: úlohou kynika je nahrádzat' falošné mravy pravdivými. ${ }^{19}$

Základné atribúty kynického života tvoria nehanebnost' (kynik nič nezakrýva), indiferentnost' (kynik je l'ahostajný voči tomu, čo sa môže stat'), schopnost' rozlišovat' (kynik rozlišuje vždy a všade medzi dobrým a chybným, medzi pravdivým a nepravdivým) a schopnost' chránit' (kynik je ako strážny pes). Život kynika sa podobá životu psa (odtial' prezývka kynikos = ,podobný psovi“). No ovel'a dôležitejšie ako prezývka je, že kynický život je vždy a za každých okolností pravdivý.

Kynik ukazuje svojím vlastným životom, že je odlišný od životov ostatných l’udí, dokonca aj od životov filosofov, ktorí hlásajú potrebu pravdivého života. ${ }^{20}$ Podl’a Foucaulta patrí myšlienka pravdivého života ako „života, ktorý je iný“ $\mathrm{k}$ najdôležitejším v dejinách západnej etiky (Foucault 2009, 226). Vysvetluje ju prostredníctvom

15 (Foucault 2001, 241). Bližšie k osvietenskému dedičstvu politickej kritiky, ktorá je založená $\mathrm{v}$ etike pozri Schwartz $(1999,128)$.

${ }^{16}$ Diog. Laert. VI 24 [= SSR V B 303]. Znenie Diogenových zlomkov sa opiera o slovenský preklad Andreja Kalaša (Cepko, Kalaš, Suvák 2016).

${ }^{17}$ Diog. Laert. VI 27 [= SSR V B 314]; porov. taktiež Diog. Laert. VI 27 - 28 [= SSR V B 374]; Dio Chrysost., Orat. VIII (7) 7 - 8; Diog. Laert. VI 57.

${ }^{18}$ Diog. Laert. VI 28 [= SSR V B 237]; Diog. Laert. VI 28 [= SSR V B 345].

${ }^{19}$ Iulian. Orat. IX 8 p. 187 B - 188 C [= SSR V B 8]; Foucault $(2009,208-210,221-224)$. Filologická analýza tohto spojenia sa nachádza v komentároch k zlomku SSR V B 2 (Cepko, Kalaš, Suvák 2016, 24 - 26).

${ }^{20}$ Epict., Dissert. III 22, 16. 
rozlíšenia medzi dvoma typmi inakosti (alterité): ${ }^{21} 1$. Spojenie „život, ktorý je iný“ (une vie autre) označuje kynickú formu pravdivého života na tomto svete, ktorá sa zásadne líši od všetkých ostatných foriem života. 2. Spojenie ,iný život“ (l'autre vie) odkazuje na svet čistých ideí a večných právd, na „iný svet“ (I'autre monde), do ktorého vstupujú duše až v momente oddelenia od tela. Je to platónsky „iný svet“, odlišný od „sveta, ktorý je iný“ (un monde autre), od „života, ktorý je iný“ (une vie autre), lebo ten zotrváva $\mathrm{v}$ tomto svete.

Kynický „život, ktorý je iný“ znamená kritiku, a zároveň radikálnu premenu tohto sveta - hladanie „sveta, ktorý je iný“. Kynický život vyjavuje sám seba ako inú formu života v tomto svete - vo svete, ktorý môžeme zmenit'. Aby mohol byt' život pravdivý, musí sa stat' „„̌ivotom, ktorý je iný““. Musí v každom momente narúšat' tradičné formy existencie. Kynická parrhésia sa tak uskutočňuje priamo uprostred toho, ako kynik žije. Táto manifestácia pravdy (alethurgia) si vyžaduje obrovskú odvahu kynik odhal'uje sám seba cez svoj život. ${ }^{22}$

Ak sa pozrieme na Sokrata z hl'adiska kynického života, ukáže sa, že modus existencie, ktorý nazýva Foucault „estetikou existencie“, by sme nemali hl'adat' uňho, aj ked' poňatie starosti o seba v Lachétovi umožňuje prístup $\mathrm{k}$ životu ako k predmetu tejto starosti. Foucault zdôvodňuje, že estetiku existencie by sme mali hl'adat' až tam, kde sa pôvodná sokratovská starost' o seba začína riadit' princípom existencie, ktorá je nanovo uchopená a prepracovaná cez princíp pravdivého hovorenia, cez princíp odvahy k pravde. Estetika existencie sa objavuje až na mieste, kde sa vytvára vzt’ah medzi umením existencie a pravdivým životom, životom v pravde. ${ }^{23}$ Pre Foucaulta sú to kynici, kto spája odvážne, neohrozené, nehanebné hovorenie pravdy so spôsobom života - odvážnym, neohrozeným, nehanebným.

Z hl'adiska dejín subjektivity Sokrates predstavuje začiatok kritického postoja v západnom myslení (Foucault 2019). Tento postoj vychádza z otázky, prečo je pre jednotlivca a pre celú spoločnost' dôležité hovorit' pravdu, poznat' pravdu? Hoci sa kynici hlásia cez Antisthena k Sokratovmu kritickému postoju, môžeme medzi nimi vidiet' určité odlišnosti. Ciel'om Sokratových problematizácií pravdy je dosiahnut' súlad medzi rozumom (logos) a spôsobom života (bios). Diogenes sa usiluje o premenu samého seba, o vytvorenie úplne odlišného štýlu existencie, o ,život, ktorý je iný““

\footnotetext{
${ }^{21}$ Táto inakost' poukazuje nielen na možnost' iného prístupu k dejinám filosofie, ale aj na ahistorický charakter metafyzického pojmu pravdy (Flynn 1987, 224).

${ }^{22}$ Novotvar alethurgia vychádza z gréckeho adjektíva aléthúrgés (,pravdivo konajúci“). Pozri Foucault $(2012,8-9)$.

${ }^{23}$ Thomas Flynn hovorí o posune od „estetiky existencie“(II. a III. zväzok Dejín sexuality) k ,estetike pravdy" (Odvaha k pravde), ktorý je súčast’ou antiplatónskej a nominalistickej stratégie v podobnom duchu ako batailleovsko-nietzscheovské čítanie Hegela (Flynn 1987, 223 - 224).
} 
(une vie autre). Kynici chcú zmenit' svoj bios tak, aby bol bezprostrednou, výbušnou a surovou prítomnost'ou pravdy (Miller 1993, 361).

Preto sa Foucault díva na kynikov ako na majstrov etiky. Preto prisudzuje kynikom, tým marginalizovaným filosofom, ktorých Hegel takmer vylúčil zo svojich $D e-$ jín filosofie, dôležité miesto v dejinách subjektivity. Aj ked' Foucault často prízvukuje, že v dejinných príkladoch nemôžeme hl'adat' riešenia pre súčasné problémy, skúmanie antickej etiky vplývalo na jeho postoj k vlastnej práci (Veyne 1986). Daniel Defert, Foucaultov partner a správca jeho pozostalosti, v roku 1996 poskytol Hermanovi Nilsonovi rozhovor, v ktorom zdôraznil blízky vzt’ah medzi Foucaultovým étosom a kynickou provokatívnou stratégiou kritiky moci. Podl’a Deferta spôsob, akým Diogenes urobil zo svojho života dlhodobú askézu a zároveň ho škandalizoval, aby zaútočil na ducha „konzervatívnych hodnôt“, má ovel’a bližšie k Foucaultovej filosofii ako Sokratova zveličovaná starost' o pravdu alebo jeho pedagogická stratégia kritického skúmania (Nilson 1998, 134).

Daniel Defert vlastne potvrdzuje to, čo je silne prítomné v posledných prednáškach Odvahy k pravde: Foucault nachádza v kynikoch filosofov, ktorí nepotrebujú na to, aby spečatili spôsob svojho života, vel’a slov. Očividne ho fascinuje, že kynizmus sa zaobíde bez dichotómie teórie a praxe. Život kynika je v každom momente viditel'ný, telesný, nesprostredkovaný, odkrytý, surový a v tomto zmysle pravdivý. Kynický život sa zakladá na skúške, ktorú musí Diogenes podstúpit' každý deň, ked' sa rozhoduje pre spôsob svojej existencie. Pravda - zviditel'nená askéza - sa zaobíde bez slov. Záverečné poznámky, ktoré si Foucault napísal k Odvahe k pravde, ale na prednáške sa $\mathrm{k}$ nim nedostal, sú akýmsi zhrnutím celého kurzu. Vracia sa v nich k problému pravdy, ktorú tradične spájame s Identitou, ale pritom je bytostne spätá s Inakost'ou - pravda je to, čo vytvára rozdiely vo svete a v mysliach l’udí, pravda je to, čo núti človeka zmenit' spôsob svojej existencie, umožňuje mu stat' sa iným. Foucault píše: „Pravda nie je nikdy rovnaká; pravda môže byt' iba vo forme iného sveta a života, ktorý je iný“ (Foucault 2009, 311). Život, ktorý je iný, odkazuje na sokratovskú tradíciu myslenia, na zásadu starosti o seba, ktorá umožňuje človeku zmenit’ spôsob svojho života, a tým získat' prístup k pravde. ${ }^{24}$ Zároveň však cítime, že Foucault má na mysli skôr Diogena ako Sokrata, ked’ hovorí o Inakosti. „Život, ktorý je iný“ (la vie autre) odkazuje priamo na kynický spôsob života, na život, ktorý sa môže zmenit' len vd’aka odvážnemu hovoreniu pravdy, len vd’aka parrhésii, ktorá je stelesneným konaním.

\footnotetext{
${ }^{24} \mathrm{~V}$ tomto duchu interpretuje Foucaultove ,posledné slová“ Leonard Lawlor, ktorý v nich nachádza hlbokú súvislost’ so Sokratovými poslednými slovami v závere Platónovho Faidóna (Lawlor 2019, 945 - 946).
} 


\section{Literatúra}

CEPKO, J. , KALAŠ, A., SUVÁK, V.: Diogenis fragmenta / Diogenove zlomky. Úvodná štúdia, preklad zlomkov a komentár. Bratislava: Vydavatel'stvo Univerzity Komenského 2016.

CEPKO, J. (2016): „Všetko patrí múdrym“: Blasfémia, alebo utópia? Filozofia, 71 (2), 131 - 140.

FLACHBARTOVÁ, L. (2014): Kynické parrhesiastické praktiky. Diogenova performatívna múdrost'. Filozofia, 69 (10), 835 - 846

FLYNN, T. (1987): Foucault as Parrhesiast: His last course at the Collège de France (1984). Philosophy and Social Criticism, 1 - 2 (2 - 3), 213 - 229.

FOUCAULT, M. (1994): Dits et écrits (1954 - 1988). Tome IV: 1980 - 1988. Defert, D. - Ewald, F. (eds.). Paris: Gallimard.

FOUCAULT, M. (2000): Etika starostlivosti o seba samého ako prax slobody. In: Foucault, M. Moc, subjekt a sexualita. Prel. M. Marcelli. Bratislava: Kalligram, 132 - 154.

FOUCAULT, M. (2001): L'Herméneutique du sujet: Cours au Collège de France, 1981 - 1982. Gros, F. (ed.). Paris: Seuil.

FOUCAULT, M. (2008): Le gouvernement de soi et des autres. Cours au College de France (1982 - 1983). Paris: Gallimard, Sueil.

FOUCAULT, M. (2009): Le courage de la verité. Le gouvernement de soi et des autres II. Cours au Collège de France (1983 - 1984). Paris: Gallimard, Seuil.

FOUCAULT, M. (2012): Du gouvernement des vivants: Cours au Collège de France, 1979 - 1980. Paris: Seuil.

FOUCAULT, M. (2019): Discourse and Truth and Parrēsia. Fruchaud, H.-P. - Lorenzini, D. (eds.). Chicago: The University of Chicago Press.

HADOT, P. (1981): Exercices spirituels et philosophie antique. Paris: Etudes Augustiniennes.

LAWLOR, L. (2019): "Sacrifice a Cock to Asclepius": The Reception of Socrates in Foucault's Final Writings. In: Moore, C. (ed.): Brill's Companion to the Reception of Socrates. Leiden: Brill, 928 - 949.

MILLER, J. (1993): The Passion of Michel Foucault. New York: Simon and Schuster.

NILSON, H. (1998): Michel Foucault and the games of truth. London: Macmillam.

SCHWARTZ, M. (1999): Repetition and Ethics in Late Foucault. Telos, 117 (1), 113 - 132.

SUVÁK, V. (2000): Prečo by nemohla byt' filozofia ako filosofia, alebo o jednom malom nenápadnom „,s“. Filozofia, 55 (5), 395 - 399.

ŠKVRNDA, F. (2017): Diogenés a Platón. Filozofia, 72 (2), 128 - 139.

VEYNE, P. (1986): Le dernier Foucault et sa morale. Critique, 471/472 (6), 933 - 941.

ZELINOVÁ, Z. (2016): Kynická paideia alebo Antisthenés medzi Odysseom a Sokratom. Filozofia, $71(2), 107-118$

Štúdia je súčast'ou riešenia grantových úloh VEGA 1/0864/18 (Ad Fontes Cynicorum Socraticorum - pramene a interpretácia sokratovského kynizmu) a VEGA 1/0094/20 (Aristippos a sokratika).

Vladislav Suvák

Inštitút filozofie

Filozofická fakulta PU v Prešove

17. novembra 1

08001 Prešov

Slovenská republika

e-mail: vladislav.suvak@gmail.com 